http://journal.unj.ac.id/unj/index.php/jpud

Volume 12 Edisi 2 November 2018

JURNAL PENDIDIKAN USIA DINI

DOI: https://doi.org/10.21009/JPUD.122

DOI: https://doi.org/10.21009/JPUD.122.11

\title{
STIMULASI METODE PERMAINAN KREATIF BERDESAIN CREATIVE MOVEMENT DALAM MENUMBUHKAN KEMAMPUAN SPASIAL ANAK DENGAN MEMPERTIMBANGKAN BUDI PEKERTI
}

\author{
Putu Aditya Antara \\ Universitas Pendidikan Ganesha \\ E-Email: putuaditya.antara@undiksha.ac.id
}

\begin{abstract}
ABSTRAK
The aims of this research to obtain empirical information from experiment on the effect of the method of creative games and character to the spatial abilities of children. This research was conducted toward children who study in group B of kindergarten at Buleleng District, Buleleng Regency, Bali in 2017. Samples were taken using multistage random sampling technique with 72 children. The empirical findings of this study indicate that there are significant use of creative movement and role play in spatial abilities of children, in addition to the spatial abilities of children who use creative movement higher than using role play. There is significant interaction between method of creative play and character to the spatial abilities of children. It was also found that the spatial abilities of children who get creative movement and has a high character gets a higher yield than the spatial abilities of children who get to role play and have a high character.
\end{abstract}

Keywords: creative movement, character, spatial abilities of children.

Tujuan penelitian ini untuk mendapatkan informasi melalui eksperimen tentang pengaruh metode permainan kreatif dan budi pekerti terhadap kemampuan spasial anak. Penelitian ini dilakukan pada anak yang belajar di kelompok B Taman Kanak-kanak yang ada pada Kecamatan

Buleleng, Kabupaten Buleleng, Bali pada tahun 2017. Sampel diambil menggunakan teknik multistage random sampling dengan 72 orang anak. Temuan empiris penelitian ini mengindikasikan bahwa terdapat pengaruh gerak kreatif dan bermain peran terhadap kemampuan spasial, selain itu kemampuan spasial anak yang menggunakan gerak kreatif lebih tinggi daripada bermain peran. Selain itu, terdapat pengaruh interaksi antara metode permainan kreatif berdesain gerak kreatif dan budi pekerti terhadap kemampuan spasial anak. Ditemukan juga bahwa kemampuan spasial anak yang mendapatkan gerak kreatif dan memiliki budi pekerti tinggi mendapat hasil yang lebih tinggi daripada kemampuan spasial anak yang mendapatkan bermain peran dan memiliki budi pekerti tinggi.

Kata kunci: gerak kreatif, budi pekerti, kemampuan spasial anak.

\section{PENDAHULUAN}

\section{Paradigma penyelenggaraan}

pendidikan anak usia dini lebih mengutamakan proses pembelajaran yang terintegrasi daripada bersifat parsial karena anak memiliki berbagai potensi yang harus dikembangkan secara maksimal untuk berbagai kemampuan dalam memecahkan 
masalah kehidupannya di masa depan. Perkembangan potensi anak yang dicapai merupakan integrasi aspek pemahaman nilai-nilai agama dan moral, kognitif, bahasa, fisik, sosialemosional serta seni (Kementerian Pendidikan dan Kebudayaan, 2015).

Melalui pengamatan peneliti pada beberapa Taman Kanak-kanak di Kecamatan Buleleng, Kabupaten Buleleng, Propinsi Bali tentang pengembangan aspek kognitif anak terlihat banyak anak-anak yang belum menguasai konsep spasial dan posisi ruang padahal kegiatan tersebut sudah sering diberikan guru dalam proses pembelajaran. Pemerolehan kemampuan spasial yang baik pada anak bisa terjadi akibat ada interaksi antara anak dengan anak lainnya. Persepsi visual yang menjadi inti dari kemampuan spasial melibatkan kepekaan anak dengan anak lainnya dalam berinteraksi sosial sehingga mereka membutuhkan sikap yang baik sekaligus nilai-nilai budi pekerti ketika melakukan proses pembelajaran di dalam kelas (Dakhi, 2001). Ketika anak mampu melakukan perilaku berbudi pekerti yang baik cenderung kelas menjadi kondusif dan produktif sehingga dalam beraktifitas anak mudah melakukan gerakan bebas tanpa dibebani konflik maupun masalah lainnya. Gerakan terstruktur dalam permainan anak pada usia taman kanak-kanak dikenal sebagai gerak kreatif (creative movement) yang dalam operasionalnya membutuhkan kebebasan ekspresi anak sehingga memberi kesempatan anak untuk membangun pengetahuan sendiri. Gerak kreatif yang merupakan bagian dari metode permainan kreatif akan mampu mengembangkan berbagai potensi yang dimiliki anak salah satunya kemampuan spasial..

Mencermati berbagai konsep idealis di atas maka penting untuk dilakukan sebuah penelitian terkait berbagai hal tersebut. Secara positivistik penelitian ini akan mengkaji pengaruh metode permainan kreatif (gerak kreatif dan bermain peran) dan budi pekerti terhadap kemampuan spasial anak taman kanak-kanak. Sesuai dengan latar belakang di atas, maka rumusan masalah dalam penelitian ini yaitu apakah terdapat perbedaan kemampuan spasial anak Taman Kanak-kanak yang diberikan gerak kreatif dan yang diberikan bermain peran?, apakah terdapat pengaruh interaksi antara variabel metode permainan kreatif dan budi pekerti terhadap kemampuan spasial anak Taman Kanak-kanak?, untuk anak Taman Kanak-kanak yang memiliki budi pekerti tinggi, apakah terdapat perbedaan kemampuan spasial anak yang diberikan gerak kreatif dengan anak yang diberikan bermain peran?, untuk anak Taman Kanak-kanak yang 
Stimulasi Metode Permainan kreatif...... Putu Aditya

memiliki budi pekerti rendah, apakah terdapat perbedaan kemampuan spasial anak yang diberikan gerak kreatif dengan anak yang diberikan bermain peran?

\section{KAJIAN TEORITIK}

\section{Kemampuan Spasial Anak}

Kemampuan spasial anak terlihat dari perkembangan kognitif yang dimiliki anak dengan mengasimilasi berbagai informasi dari lingkungan sosial sekitar anak. Konsep kemampuan spasial dijelaskan Smith dengan menyatakan bahwa perkembangan kemampuan spasial membutuhkan pengalaman topologis yang dilatih melalui pengalaman anak mempelajari ruang dengan berbagai bentuk dan ukuran. Konsep topologis tersusun dengan berbagai konsep yaitu (1) kedekatan (proximity) yang berupa konsep hubungan antar anak terhadap objek, (2) pemisahan (separation) yang bermakna sebuah objek selalu terdiri dari bagian-keseluruhan (3) urutan (order) merupakan pemahaman akan konsep sebelum-sesudah (4) pembatasan (enclosure) merupakan posisi objek yang dibatasi benda yang ada disekitarnya baik itu atas dan bawah, kanan dan kiri, sisi depan dan belakang (Smith, 2009).

Memperhatikan berbagai

konsep di atas maka kemampuan spasial adalah kesanggupan anak untuk memahami dan mengungkapkan konsep ruang dengan aspek kedekatan, pemisahan, urutan, pembatasan, dan ukuran.

\section{Gerak Kreatif (Creative Movement)}

Gerak kreatif digunakan sebagai cara mengekspresikan diri anak secara bebas sesuai dengan imajinasinya. Dengan mengekspresikan berbagai imajinasinya anak mampu mengembangkan berbagai potensi lainnya. Menurut Dodge dan Colker gerak kreatif memberikan kontribusi besar pada sosial-emosional, kognitif, dan perkembangan fisik anak (Dodge, 2000). Selanjutnya, Hawkins menegaskan kembali kegiatan yang perlu dilakukan dalam pelaksanaan gerak kreatif yang dikaitkan dengan proses kreatif yaitu merasakan (menyerap), menghayati, mengkhayalkan, mengejawantahkan dan memberi bentuk (Hawkins \& Bibia, 2003).

Mencermati berbagai pendapat di atas, dapat disimpulkan bahwa gerak kreatif adalah gerak yang dikombinasikan untuk mengekspresikan pengalaman batin dan mengungkapkan perasaan seseorang serta dilakukan dengan memberikan kebebasan pada anak untuk bergerak sesuai imajinasinya dengan memperhatikan waktu, ruang dan penekanan serta memiliki tahapan merasakan (menyerap), menghayati, 
menghayalkan, mengejawantahkan dan memberi bentuk.

\section{Bermain Peran (Role Play)}

Konsep bermain peran (role playing) sendiri berakar pada hakikat manusia sebagai makhluk individu dan sosial. Tahapan bermain peran memiliki beberapa prosedur yang jelas yang terdiri dari mempelajari konteks, membuat daftar materi, mempersiapkan peralatan dan mengatur lokasi, menyampaikan topik dan teknis pelaksanaannya, mempraktekkan, bermain peran yang menyenangkan, menghayati, mengajak anak menyimpulkan aktivitas bermain peran(Lendrum, 2001). Secara khusus tentang bermain peran, Erikson mengatakan bahwa bermain peran memiliki tahapan bermain sesuai dengan usia yang dimiliki oleh anak seperti autocosmic play yaitu bermain pada usia tahun pertama dalam peran mengeksplorasi seluruh tubuhnya contohnya meraba wajah, microspheric play yaitu bermain pada usia dua tahun dalam perannya sebagai manusia yang mulai mengenal berbagai objek yang lebih kecil untuk dimainkan contohnya bermain mobil-mobilan kecil, macrospheric play yaitu bermain anak sekitar usia tiga tahun dalam perannya sebagai individu yang mulai mengenal lingkungan sosial masyarakat seperti bermain peran dokter-dokteran (Sheridan, 2011).

Mencermati berbagai teori dan pendapat yang dikemukakan di atas dapat disimpulkan bahwa bermain peran adalah proses pembelajaran melalui bermain agar anak menemukan makna dan peran diri (jati diri) dalam dunia sosial. Adapun langkah yang digunakan dalam kegiatan bermain peran yaitu mempelajari konteks, membuat daftar materi, mempersiapkan peralatan, menyampaikan topik, mempraktekkan bermain peran, menghayati peran, menyimpulkan aktivitas dalam bermain peran.

\section{Budi Pekerti}

Perkembangan budi pekerti anak sangat dipengaruhi oleh kondisi anak dan lingkungan sosialnya, baik orang tua, teman sebaya dan masyarakat sekitar. Selanjutnya Zuriah mengatakan bahwa pendidikan budi pekerti merupakan program pengajaran di sekolah yang bertujuan mengembangkan watak atau tabiat siswa dengan cara menghayati nilainilai dan keyakinan masyarakat sebagai kekuatan moral dalam hidupnya melalui kejujuran, dapat dipercaya, empati, disiplin, dan bertanggung jawab yang menekankan ranah afektif (perasaan dan sikap) tanpa meninggalkan ranah kognitif (berpikir rasional) dan ranah 
Stimulasi Metode Permainan kreatif...... Putu Aditya

skill/psikomotorik (terampil mengolah informasi, dan kerja sama) (Zuriah, 2008). Hal ini secara lebih detail ditegaskan Dewantara dengan mengatakan bahwa tujuan pendidikan budi pekerti adalah agar anak dapat ngerti, ngrasa, dan nglakoni (menyadari, menginsyafi, dan melakukan) perbuatan yang sesuai dengan norma-norma yang dianut masyarakat (Dewantara, 2004). Namun disisi lain, harus dipahami bersama bahwa perbedaan pengasuhan yang diberikan pada anak akan menterjadikan perbedaan kepemilikan nilai budi pekerti anak sehingga dalam konteks penilaian akan ada kategori budi pekerti anak yang tergolong tinggi dan tergolong rendah. Terkait hal itu maka penelitian ini akan meninjau tinggi dan rendah budi pekerti yang dimiliki anak.

Memperhatikan berbagai pendapat di atas maka dapat dikatakan bahwa budi pekerti adalah nilai-nilai perilaku yang mengembangkan potensi-potensi pembawaan manusia untuk berperilaku baik, benar dan tepat dengan memperhatikan aspek-aspek seperti kerjasama, komunikasi, empati, memahami aturan, dan bertanggung jawab yang diimplementasikan dengan komprehensif berdasarkan pada nilai mulia dan budaya yang ada dalam masyarakat.

\section{METODOLOGI PENELITIAN}

Metode penelitian yang digunakan dalam penelitian ini adalah metode eksperimen dengan Kemampuan Spasial sebagai variabel terikat sedangkan variabel bebas berupa Metode Permainan kreatif (dalam penelitian ini adalah kegiatan Gerak Kreatif dan kegiatan Bermain Peran) dan Budi Pekerti. Penelitian ini merupakan penelitian eksperimen dengan rancangan desain treatment by level $2 \times 2$. Oleh karena itu, analisis data menggunakan ANAVA dua jalur, jika teruji adanya perbedaan, dilanjutkan dengan Uji Tukey untuk menentukan mana yang lebih tinggi.

Kedua variabel baik Kemampuan Spasial dan Budi Pekerti datanya diambil menggunakan instrumen otentik dengan model rubrik. Kriteria yang digunakan untuk mengukur kemampuan spasial yaitu skor 1, 2 dan 3. Dengan kategori $3=\operatorname{mampu}, 2=$ sedang, 1 = tidak mampu. Data dikumpulkan dalam waktu 7 bulan pada bulan April 2017 sampai dengan Oktober 2017 di kelompok B Taman Kanak-kanak Lab School Undiksha dan Taman Kanak-kanak Negeri Pembina. Instrumen variabel-variabel ini telah telah valid dan reliabel serta dilakukan uji reliabilitas antar rater dengan status reliabel juga. Populasi terjangkau dalam penelitian ini adalah kelompok B Taman Kanak-kanak di Kecamatan Buleleng yang berjumlah 
24 kelas pada 14 Taman Kanak-kanak. Sedangkan populasi tidak terjangkau yaitu seluruh kelompok B Taman Kanak-kanak di Kabupaten Buleleng yang berjumlah 120 kelas pada 59 Taman kanak-kanak. Penentuan sampel menggunakan teknik multistage random sampling dengan jumlah sampel penelitian sebanyak 72 orang anak dengan rincian masingmasing kelompok penelitian sejumlah 18 orang anak.

\section{HASIL DAN PEMBAHASAN}

Berdasarkan analisis variansi dua jalur yang merupakan suatu teknik perhitungan yang bertujuan untuk menyelidiki dua pengaruh, yaitu main effect dan interaction effect dapat dipaparkan sebagai berikut.

Tabel 01. Rangkuman perhitungan ANAVA Dua Jalur

\begin{tabular}{cccccc}
\hline Sumber Variansi & db & JK & RJK & F hitung & Ftabel \\
\hline Metode Permainan Kreatif (A) & 1 & 117,56 & 117,56 & $4,612^{*}$ & 3,98 \\
Budi Pekerti (B) & 1 & 107,56 & 107,56 & $4,220^{*}$ & 3,98 \\
Interaksi (A x B) & 1 & 760,50 & 760,50 & $29,838^{*}$ & 3,98 \\
Kekeliruan & 68 & 1733,17 & 25,49 & & \\
Jumlah & 71 & 2718,78 & & & \\
\hline
\end{tabular}

Berdasarkan pada hasil analisis ANAVA yang terdapat pada rangkuman di atas, maka dapat dijelaskan sebagai berikut:

Kemampuan Spasial anak yang diberikan permainan gerak kreatif lebih tinggi dari anak yang

\section{diberikan permainan bermain peran.}

Mencermati perhitungan Analisis varians dua jalur tentang perbedaan kemampuan spasial pada kelompok anak yang diberikan gerak kreatif dan bermain peran seperti pada tabel rangkumam hasil uji analisis, menunjukkan bahwa $\mathrm{F}$ (hitung) = 4,612 dan $\mathrm{F}($ tabel $)=3,98$ pada taraf signifikansi 0,05, maka $\mathrm{F}$ (hitung) > $\mathrm{F}$ (tabel). Dengan demikian $\mathrm{H}_{0}$ ditolak, sehingga dapat disimpulkan bahwa secara keseluruhan terdapat perbedaan kemampuan spasial antara anak yang diberi gerak kreatif dan bermain peran.

Menurut hasil analisis data pada hipotesis pertama dari penelitian ini menunjukkan bahwa secara keseluruhan gerak kreatif memberikan pengaruh yang lebih baik dibandingkan dengan bermain peran terhadap kemampuan spasial anak. Hasil analisis tersebut sesuai dengan pernyataan Martin, bahwa melalui gerak kreatif merupakan gerak yang bisa mengungkapkan ekspresi dari segala pengalaman emosional manusia dan pengalaman fisik yang paling elementer sehingga sangat dinikmati anak (Martin, 1965). Sedangkan pada kegiatan bermain peran anak lebih menikmati akan peran dalam kehidupan sosial dan mencari pemecahan masalah dalam kehidupan kelompok meskipun dalam implementasi pelaksanaannya 
Stimulasi Metode Permainan kreatif...... Putu Aditya

pengembangan konsep ruang tetap diberikan, namun hasil penelitian ini menunjukkan bahwa gerak kreatif jauh lebih efektif dari bermain peran dalam meningkatkan kemampuan spasial anak, khususnya yang menjadi subjek dalam penelitian ini.

\section{Pengaruh interaksi antara Metode Permainan Kreatif dan Budi Pekerti terhadap Kemampuan Spasial anak}

Berdasarkan pada hasil analisis varians (ANAVA) dua jalur dengan taraf signifikasi $\alpha=0,05$ diperoleh perhitungan $F$ interaksi sebesar 29,838 dan Ft sebesar 3,98, maka $\mathrm{F}$ (hitung) $>\mathrm{F}$ (tabel). Dengan demikian $\mathrm{H}_{0}$ ditolak, dapat disimpulkan bahwa terdapat pengaruh interaksi antara metode permainan kreatif dan budi pekerti terhadap kemampuan spasial anak.

Pengujian pada hipotesis yang kedua melalui analisis varians dua jalur menunjukkan terdapat pengaruh interaksi antara permainan kreatif dan budi pekerti terhadap kemampuan spasial anak. Dengan demikian dapat dinyatakan bahwa kemampuan spasial anak tergantung pada permainan kreatif yang diberikan dan budi pekerti anak. Gerak kreatif memberikan pengaruh lebih baik terhadap kemampuan spasial anak yang memiliki budi pekerti tinggi. Sedangkan anak yang memiliki budi pekerti rendah lebih baik diberikan bermain peran dibandingkan gerak kreatif. Hal ini sangat beralasan karena gerak kreatif memberikan kesempatan kepada anak untuk bebas bergerak sambil memahami ruang dengan lebih maksimal (Hawkins \& Bibia, 2003).

Karena terdapat interaksi antara anak yang diberikan permainan gerak kreatif dan permainan bermain peran terhadap kemampuan spasial anak, maka analisis dilanjutkan untuk pengujian simple effect dengan Uji Tuckey. Hasil perhitungan tersebut disesuaikan dengan kriteria pengujian uji Tuckey bahwa Terima $\mathrm{H}_{0}$ jika $\mathrm{Q}_{\text {hitung }} \leq \mathrm{Q}_{\text {tabel }}$ dan Tolak Ho jika $\mathrm{Q}_{\text {hitung }}$ $>\mathrm{Q}_{\text {tabel }}$ maka antara kelompok $\mathrm{A}_{1} \mathrm{~B}_{1}$ $\mathrm{A}_{2} \mathrm{~B}_{1}$ didapatkan $Q_{\text {hitung sebesar 7,61 }}$ lebih besar dari $Q_{\text {tabel }}$ sebesar 3,74 maka kesimpulannya tolak $\mathrm{H}_{0}$ sedangkan antara kelompok $\mathrm{A}_{1} \mathrm{~B}_{2}$ $\mathrm{A}_{2} \mathrm{~B}_{2}$ didapatkan $\mathrm{Q}_{\text {hitung }}$ sebesar 3, 31 lebih kecil dari $Q_{\text {tabel }}$ sebesar 3, 74 maka kesimpulannya $\mathrm{H}_{0}$ diterima. Penjelasan lebih jauh tentang pengujian simple effect akan dideskripsikan di bawah ini.

Perbedaan Kemampuan Spasial anak yang memiliki Budi Pekerti tinggi antara yang diberikan permainan Gerak Kreatif (creative movement) dan permainan Bermain Peran.

Mencermati hasil pengujian lanjut dengan menggunakan uji Tuckey, 
diperoleh harga Qhitung sebesar 7,61 lebih besar dari $Q_{\text {tabel }}$ pada taraf signifikansi $\alpha=0,05$ dengan $\mathrm{n}=18$ dan $\mathrm{db}_{\text {kekeliruan }}=68$ didapatkan $\mathrm{Q}_{\text {tabel }}$ sebesar 3,74, maka $Q_{\text {hitung }}>Q_{\text {tabel }}$ sehingga $\mathrm{H}_{0}$ ditolak. Dengan demikian dapat disimpulkan bahwa terdapat perbedaan yang sangat signifikan kemampuan spasial anak memiliki budi pekerti tinggi yang distimulasi dengan gerak kreatif dibandingkan yang distimulasi dengan bermain peran. Selain itu dapat dikatakan pula bahwa kemampuan spasial anak lebih tinggi pada anak yang distimulasi dengan gerak kreatif dan memiliki budi pekerti tinggi dibandingkan kemampuan spasial anak yang distimulasi dengan bermain peran dan memiliki budi pekerti tinggi.

Terkait hipotesis penelitian ketiga, dapat dikatakan bahwa kemampuan spasial anak yang memiliki budi pekerti tinggi lebih tinggi atau baik dibandingkan anak yang memiliki budi pekerti rendah. Hal ini sesuai dengan sintesa teori pada kajian teoretik, bahwa budi pekerti yang dimiliki anak bisa membangun identitas perseptual dari sebuah objek serta mampu mempermudah anak memahami materi karena anak lebih tenang serta komunikatif dengan temannya. Dengan budi pekerti tinggi dan diberikan gerak kreatif tentu materi pembelajaran di kelas akan terekam dengan baik dalam pikiran jika memiliki respon yang baik pula ketika informasi visual diterima. Jika terjadi respon yang tidak baik ketika menerima informasi spasial maka perhatian terhadap objek akan menurun dan informasi spasial tidak bisa diterima secara utuh bahkan tidak detail (Hurlock, Elisabeth, 1978).

\section{Perbedaan Kemampuan Spasial anak yang memiliki Budi Pekerti rendah antara yang diberikan permainan gerak kreatif dan permainan bermain peran.}

Memperhatikan hasil pengujian lanjut dengan menggunakan uji Tuckey, diperoleh harga Qhitung sebesar 3,31 lebih kecil dari Qtabel pada taraf signifikansi $\alpha=0,05$ dengan $\mathrm{n}=$ 18 dan $\mathrm{db}_{\text {kekeliruan }}=68$ didapatkan $\mathrm{Q}_{\text {tabel }}$ sebesar 3,74, maka Qhitung $<Q_{\text {tabel }}$ sehingga $\mathrm{H}_{0}$ diterima. Dengan demikian dapat disimpulkan bahwa tidak terdapat perbedaan yang signifikan kemampuan spasial anak yang memiliki budi pekerti rendah yang distimulasi menggunakan gerak kreatif dibandingkan dengan yang distimulasi menggunakan bermain peran. Namun disisi lain, ditemukan bahwa kemampuan spasial anak lebih rendah pada anak yang distimulasi gerak kreatif dan memiliki budi pekerti rendah dibandingkan dengan kemampuan spasial anak yang 
Stimulasi Metode Permainan kreatif...... Putu Aditya

distimulasi dengan bermain peran dan memiliki budi pekerti rendah.

Sesuai dengan pengujian hipotesis yang keempat, ditunjukkan bahwa tidak terdapat perbedaan yang signifikan pada kemampuan spasial anak yang memiliki budi pekerti rendah yang distimulasi menggunakan gerak kreatif dibandingkan dengan yang distimulasi menggunakan bermain peran. Dilihat secara realitas sosial, temuan ini bisa sangat beralasan jika dikaitkan dengan kondisi masyarakat yang sebenarnya. Jika dicermati pada gerak kreatif beserta tahapan pelaksanaan kegiatannya, terlihat jelas gerak kreatif mudah dipahami oleh berbagai karakteristik anak (Leseho, Johanna dan Maxwell, 2010). Sehingga anak yang memiliki budi pekerti rendah pun tentu mudah menguasai seluruh gerak yang dilakukan dalam proses stimulasi gerak kreatif. Hal inilah yang menyebabkan gerak kreatif mudah dipahami dan dikuasi oleh anak meskipun dengan budi pekerti rendah dan tentunya berpengaruh dengan kemampuan spasial anak.

\section{KESIMPULAN, IMPLIKASI DAN SARAN}

Memperhatikan hasil penelitian dan pembahasan yang telah dijelasakan pada bagian sebelumnya maka kesimpulan dari penelitian yaitu terdapat perbedaan kemampuan spasial antara anak yang mendapatkan permainan kreatif berdesain gerak kreatif dengan anak yang diberikan permainan kreatif berdesain bermain peran. Hal ini ditegaskan pada hasil penelitian menyatakan bahwa kemampuan spasial anak yang mendapatkan gerak kreatif lebih tinggi dari pada yang mendapatkan bermain peran. Pertama, secara keseluruhan terdapat pengaruh penggunaan permainan kreatif terhadap kemampuan spasial anak. Kedua, terdapat pengaruh permainan kreatif terhadap kemampuan spasial anak bergantung pada budi pekerti. Ketiga, kemampuan spasial anak yang mendapatkan permainan kreatif dengan gerak kreatif dan memiliki budi pekerti tinggi, lebih tinggi daripada kemampuan spasial anak yang mendapatkan permainan kreatif dengan bermain peran dan memiliki budi pekerti tinggi. Penelitian ini berimplikasi pada pengembangan nilai moral dan agama anak karena kemampuan spasial yang dikembangkan dengan memperhatikan budi pekerti anak akan membuat anak memiliki kesantunan dan pengaturan diri untuk bersikap lebih baik sesuai nilai dan aturan yang ada. Saran kepada guru, agar mengembangkan kemampuan spasial anak dengan memperhatikan budi pekerti anak dan menggunakan permainan kreatif berbentuk gerak 
JURNAL PENDIDIKAN USIA DINI

Volume 12 Edisi 2, November 2018
E-ISSN:2503-0566 kreatif dalam proses pembelajaran secara berkelanjutan, selain itu kepada peneliti lain agar meneliti tentang pengembangan gerak kreatif untuk aspek selain kognitif seperti sosial emosional, dan bahasa.

\section{DAFTAR PUSTAKA}

Dakhi, E. Y. Z. dkk. (2001). Terbang dengan Dua Sayap; Sukses Pelatihan Budi Pekertitle. Jakarta: PT Grasindo

Dewantara, K. H. (2004). Bagian Pertama: Pendidikan. Yogyakarta: Majelis Luhur Persatuan Taman Siswa.

Dodge, D. T. \& C. (2000). No Title. Washington: Teaching Strategic inc.

Hawkins, A. M., \& Bibia, I. W. (2003). Bergerak Menurut Kata Hati. Metode Baru dalam Menciptakan Tari. Jakarta: Ford Foaundation dan Masyarakat Seni Indonesia.

Hurlock, Elisabeth, B. (1978). Perkembangan Anak, Jilid 2. Jakarta: Erlangga.

Kementerian Pendidikan dan
Kebudayaan. Peraturan Menteri Pendidikan dan Kebudayaan Republik Indonesia No. 137 Tahun 2013 tentang Standar Nasional Pendidikan Anak Usia Dini (2015).

Lendrum, S. (2001). Case Material and Role Play in Counseling Training. New York: Routledge.

Leseho, Johanna dan Maxwell, L. R. (2010). Coming alive: CREATIVE MOVEMENT as a Personal Coping Strategy on The Path To Healing and Growth. British Journal of Guidance \& Counselling, 38.

Martin, J. (1965). The Modern Dance. New York: Dance Horizons, Inc.

Sheridan, M. D. (2011). Play in Early Childhood: From Birth to Six. New York: Routledge.

Smith, S. S. (2009). Early Childhood Mathematics. Boston: Pearson Education.

Zuriah, N. (2008). Pendidikan Moral \& Budi Pekerti dalam Perspektif Perubahan; Menggagas Platform Pendidikan Budi Pekerti secara Kontekstual dan Futuristik. Jakarta: Bumi Aksara. 